\title{
Development of species specific primer for the early detection of Cylindrocladium quinqueseptatum causing leaf and seedling blight in Eucalyptus
}

\author{
Amit Pandey, Partha Sarathi Mohanty and Pooja Arya \\ Forest Pathology Division, Forest Research Institute, Dehradun, INDIA \\ ABSTRACT
}

\begin{abstract}
We developed PCR primers to detect Cylindrocladium quinqueseptatum which infect Eucalyptus causing leaf and seedling blight resulting in heavy seedling mortality in North Indian states. Primers based on sequence analysis of internal transcribed spacer region 1 and $5.8 S$ of ribosomal DNA produced PCR product of $245 \mathrm{bp}$. The internal transcribed spacer (ITS) of the ribosomal DNA (rDNA) sub unit repeat was sequenced in 26 isolates of Cylindrocladium quinqueseptatum and sequences were aligned and compared with the ITS sequences of other fungi in GenBank. No amplification resulted from PCR reactions on fungal DNA from 6 common forest fungi, 10 soil contaminates and 6 Eucalyptus pathogens. For amplifications directly from infected tissues, a nested primer PCR using two rounds of amplification was done. First, the entire ITS was amplified with universal fungal primer; a second round of amplification was carried out with species specific primer that amplified a $245 \mathrm{bp} \mathrm{PCR} \mathrm{product.} \mathrm{The} \mathrm{method} \mathrm{detected} \mathrm{leaf}$ and seedling blight in artificially and naturally infected Eucalyptus plants. From the soil also the pathogen was detected using species specific primer. In sampling studies, C. quinqueseptatum was detected by PCR from artificially infected seedlings at 6 days post inoculation, before any visible symptoms were present. The PCR assay and direct tissue extraction methods provide tools which may be used to detect $C$. quinqueseptatum from soil, plant cuttings and adjoining Eucalyptus plantations serving as recurring source of infection and thus limit the transmission and spread of new aggressive strains of $C$. quinqueseptatum in Eucalyptus growing regions of India.
\end{abstract}

Keywords: Cylindrocladium quinqueseptatum, internal transcribed spacer, nested PCR

\section{INTRODUCTION:}

Large scale seedling mortality in Eucalyptus nurseries of North Indian states caused by Cylindrocladium quinqueseptatum has posed serious threat to paper and pulp industries of this region fearing decline in production, as majority of industrysponsored nurseries raised by local farmers for achieving the plantation targets have witnessed this disease in epipytotic proportions in the recent years. Major losses in planting stock material is expected in future also if new advances in control and detection technologies are not made. Worst affected North Indian states are Uttarakhand, Punjab and Haryana. Losses from Cylindrocladium quinqueseptatum seedling blight is due to out right killing of the entire seedling within a couple of weeks time during monsoon season and blightening of leaves in plantations thus adversely affecting the tree growth. Apparently healthy seedlings develop blight symptoms and die quickly in short span of 8 to 15 days leaving little time for the application of remedial measures. The three sources of inoculum are the perennating $C$. quinqueseptatum in plant debris of nursery soil, infected propagules and the adjoining
Eucalyptus trees harboring pathogen on their twigs and leaves. The seedlings raised in the subsequent years eventually suffer heavy losses with the every passing year due to increase in inoculum build up. The severity of recent losses and the fact that the infected planting materials are transported across the three states of northern India viz. Punjab, Haryana and Uttarakhand in different plantation programms may have served as the primary source of inoculum, has necessitated the development of rapid and sensitive method for detection of leaf and twig blight of Eucalyptus in early stages, preferably prior to nursery raising and before the onset of monsoon. Sites selection for raising nurseries also needs to be checked for residual presence of pathogen over wintering in the soil and on surrounding Eucalyptus plantations. Such a test would allow the determination of levels of infection in host propagules, nursery soil and adjoining Eucalyptus plantations which are being utilized for the production or as source material for raising planting stock. Among the nursery managers and farmers, currently the disease detection is based solely on visual inspection of seedlings, a procedure in which infected but symptomless Eucalyptus saplings escape 
Agric. Biol. J. N. Am., 2010, 1(6): 1253-1259

detection. Visual inspection is also complicated by the similarity of symptoms caused by other organisms and the potential of confusing Cylindrocladium infection with other leaf spot pathogens such as Cryptosporiopsis eucalypti, Mycosphaerella spp. etc which may be present as primary or secondary infection. This also causes difficulty in isolating $C$. quinqueseptatum in pure culture as the fast growing pathogens like Cryptosporiopsis eucalypti quickly covers the culture plates, often causing disagreement on the pathogen involved.

Various molecular approaches have been used to differentiate Cylindrocladium species, including use of ribosomal DNA (rDNA) and beta tubulin gene (Henricot and Culham, 2002). The internal transcribed spacer (ITS) region of rDNA and PCR have proven useful in differentiating a wide variety of fungi including Phytopthora (Tooley et al., 1997), Pythium (Chen, 1992), Peronosclerospora (Yao, 1992), mycorrhizae and rusts (Gardes and Bruns, 1993), Verticillium (Nazar et al., 1991), Fusarium (O'Donnell, 1992) and others (Hadidi et al., 1995; Henson and French, 1993). PCR oligonucleotide primers named CPAUCIR/CPAUCIF were designed from b-tubulin gene sequences to improve detection of C. pauciramosum (Camele et al., 2009). Two internal primers were synthesized for the specific amplification of portions of the ITS for C. floridianum, and two primers were designed to amplify three variants of Cylindrocarpon destructans (Hamelin et al., 1996).

The objective of the present study was to develop a PCR-based assay for detecting and distinguishing the $C$. quinqueseptatum which infects Eucalyptus species. A more specific aim was to develop a DNAbased method to identify $C$. quinqueseptatum from Eucalyptus foliar or twig tissues, and soil. The assay we described allows rapid, sensitive detection of leaf and twig blight caused by $C$. quinqueseptatum thus representing a new tool potentially useful in early detection of this pathogen from soil and pre symptomatic nursery and planting stock. It will also be useful in epidemiological studies. During the course of this investigation we were also able to obtain molecular evidence for the presence of only one species of Cylindrocladium i.e., Cylindrocladium quinqueseptatum in North Indian states in contrast to the South Indian states where at least 10 species of Cylindrocladium is reported to cause different diseases in Eucalyptus (Sharma and Mohanan, 1982).

\section{MATERIALS AND METHODS:}

Infected materials: Twenty four infected leaf and twig samples of Eucalyptus were collected from different nurseries and plantations in three North Indian states viz, Punjab, Haryana and Uttarakhand. From another North Indian state Uttar Pradesh one isolate was collected. One isolate from eastern part of India (Orissa) was also included in this study for comparison. These twenty six isolates were collected from ten nurseries and nine plantations of Eucalyptus. For isolating C. quinqueseptatum $5 \times 10$ $\mathrm{mm}$ leaf pieces and $10 \mathrm{~mm}$ long twig pieces were aseptically excised from Eucalyptus plant samples showing disease symptoms, placed on potato dextrose agar (PDA), and incubated for seven days at $25^{\circ} \mathrm{C}$. Meanwhile, the diseased plant samples and soil samples collected were stored at $2^{\circ} \mathrm{C}$. All the soil and disease samples were subsequently transferred into a freezer at $-20^{\circ} \mathrm{C}$ until DNA was extracted from them. C. quinqueseptatum was also isolated from the soil samples taken from the above mentioned nurseries and plantations by serial dilution method and incubation at $25^{\circ} \mathrm{C}$ on PDA for seven days.

Fungal isolates: All the above mentioned twenty six C. quinqueseptatum isolates were used for further studies. For validating the $C$. quinqueseptatum species specific primer designed during the course of study, additional fungal species were either isolated from the Eucalyptus samples from the study area (2 isolates of each Eucalyptus pathogen) viz., Cryptosporiopsis eucalypti, Phaeophleospora sp, Alternaria sp, Botrytis cinerea, Pestalotiopsis sp and Cylindrocladium scoparium or obtained from National Type Culture Collection (NTCC), Forest Pathology Division, Forest Research Institute, Dehradun, India viz, Fusarium solani, Colletotrichum gloeosporioides, Pycnoporus sanguineus, Trametes versicolor and Ganoderma lucidum. Cultures belonging to the genus Cylindrocladium were transferred to carnation leaf agar dishes until the formation of conidia and vesicles to confirm the species (Crous and Wingfield, 1994). The taxonomic identification of other fungal pathogens of Eucalyptus was done by standard keys based on their morphological, cultural and sporulation characteristics. Twenty six isolates of $C$. quinqueseptatum that clearly satisfied the species criteria as mentioned by Crous and Wingfield, (1994) were included for sequencing and as positive controls for the species specific primers. These isolates were grown in liquid broth at $25^{\circ} \mathrm{C}$ for ten days. The mycelium was then filtered through filter paper 
Agric. Biol. J. N. Am., 2010, 1(6): 1253-1259

(Whatman no.1) and rinsed with sterile distilled water, lyophilized and stored at $-20^{\circ} \mathrm{C}$ until DNA extraction. Ten fungal contaminants commonly encountered while isolating microbes from soil were cultured and processed for DNA extraction. These include Aspergillus niger, A. flavus, Trichoderma harzianum, T. viride, $T$. koningii, $T$. virens, Fusarium sp, Phomopsis sp, Cladosporium sp and Penicililum sp.

DNA extraction: DNA extraction from the mycelium was done according to the protocol described by Zolan and Pukkila (1986). Approximately $10 \mathrm{mg}$ lyophilized mycelium was ground in liquid nitrogen and mixed with $700 \mu \mathrm{l}$ of extraction buffer $(700 \mathrm{mM}$ $\mathrm{NaCl}, 50 \mathrm{mM}$ Tris-HCl [pH-8], 10 mMEDTA, 1\% $\beta-$ 2 mercaptoethanol and $1 \%$ cetyl-trimethyl ammonium bromide). The mixture was incubated at $65^{\circ} \mathrm{C}$ for 1 hour and extracted by adding an equal volume of chloroform-isoamyl alcohol (24:1), vortexed, and centrifuged for $10 \mathrm{~min}$ at $10,000 \mathrm{~g}$. The aqueous phase was precipitated with cold isopropanol and centrifuged at $10,000 \mathrm{~g}$ for $10 \mathrm{~min}$. The pellets were washed with $70 \%$ ethanol, air dried, resuspended in $50 \mu$ of TE buffer (10 mM Tris- $\mathrm{HCl}[\mathrm{pH}-8], 1 \mathrm{mM}$ EDTA), and stored at $-20^{\circ} \mathrm{C}$ until needed.

DNA extractions directly from leaves and twigs were done by the method described by Saghai-Maroof et al. (1984). DNA extraction directly from soil was done according to the protocol described by VazquezMarrufo (2002) with slight modification. $10 \mathrm{gm}$ of soil was ground into fine powders in liquid nitrogen and transferred to $50 \mathrm{ml}$ of polypropylene tubes. $20 \mathrm{ml}$ of lysis buffer (100mM Tris- $\mathrm{HCl}$ [pH 8.0], 50mM EDTA, $50 \mathrm{mM} \mathrm{NaCl}, 10 \%$ [W/V] SDS) was added to the tube and incubated at $65^{\circ} \mathrm{C}$ for 15 min with shaking. $10 \mathrm{ml}$ of benzyl chloride was added to the mixture and vortexed for $3 \mathrm{~min}$ and incubated at $65^{\circ} \mathrm{C}$ for $15 \mathrm{~min}$ with shaking. $10 \mathrm{ml}$ of Tris saturated phenol was added to the mixture and mixed gently on ice for 10 min. The mixture was centrifuged at $10,000 \mathrm{~g}$ for 15 min. Aqueous phase was transferred to fresh tubes and DNA was precipitated by adding an equal volume of ice cold isopropanol and centrifuged for 10 $\min$ at $10,000 \mathrm{~g}$. The pellets were washed twice in $70 \%$ ethanol, air dried, resuspended in $50 \mu \mathrm{l}$ of TE buffer and stored at $-20^{\circ} \mathrm{C}$ until needed.

DNA amplification, purification and sequencing:

The entire region containing both internal transcribed spacers (ITS I and ITS II) and 5.8S rDNA repeat unit was amplified with primers ITS1 (5'TCCGTAGGTGAACCTGCGG-3') and ITS4 (5'TCCTCCGCTTATTGATATGC-3'). PCR reactions were carried out in $25 \mu \mathrm{l}$ of reaction mixture containing $10 \mathrm{mM}$ Tris- $\mathrm{HCl}(\mathrm{pH}-8.3), 50 \mathrm{mM} \mathrm{KCl}, 1.5 \mathrm{mM} \mathrm{MgCl}_{2}$, $0.0001 \%$ gelatin, $400 \mu \mathrm{M}$ dNTPs, $1 \mu \mathrm{M}$ of each forward and reverse primers, 1 unit of Taq DNA polymerase and $1 \mu \mathrm{l}(20 \mathrm{ng})$ of template DNA. The reactions were carried out in a gradient thermal cycler with an initial denaturation temperature of $96^{\circ} \mathrm{C}$ for 3 minutes, followed by 30 cycles of $92^{\circ} \mathrm{C}$ for 30 seconds, $58^{\circ} \mathrm{C}$ for 45 seconds and $72^{\circ} \mathrm{C}$ for 1 minute. The reaction was completed by a final extension temperature of $72^{\circ} \mathrm{C}$ for 10 minutes. All the PCR products were purified and sequenced at Genomic Lab of Axygen India Pvt. Ltd, New Delhi, India.

Primer synthesis and two-step nested PCR: Sequences of ITS region were deposited in GenBank, NCBI, USA and accession numbers were obtained for all the $26 \mathrm{C}$. quinqueseptatum isolates of our collection viz. Uttarakhand (FJ601687, FJ601688, FJ601693, FJ601694, FJ601695, FJ601699, FJ601700, FJ601701, FJ601702, FJ601703, FJ868786, FJ868788, FJ868789, FJ868791, FJ868792), Haryana (FJ601690, FJ601691, FJ601692, FJ601696, FJ868790), Punjab (FJ601697, FJ601698, FJ868787, FJ868793), Uttar Pradesh (FJ601689) and Orissa (FJ601704). ITS region sequences of all the 26 isolates were aligned and compared with sequences of $C$. quinqueseptatum (AF232868, AF232869, AF232870) and other species of Cylindrocladium available in GenBank, using DNAMAN (version 4.0; Lynnon Biosoft, Quebec, Canada). Three sets of forward and reverse primers, specific to $C$. quinqueseptatum were designed using Primer Premier 5.0 software (Premier Biosoft International., CA, USA), which sets oligonucleotide sizes, PCR product size, positional constrain and GC content within the source sequence. The primers were synthesized by IDT (Integrated DNA Technologies, Inc. Coralville, USA) to yield a PCR product of $245 \mathrm{bp}$ by the set parameters.

A nested PCR approach was used for detection of pathogen from infected tissues, post inoculation presymptomatic seedlings and soil samples of nurseries and plantations and also DNA templates of the six common Eucalyptus pathogens, five NTCC fungal cultures and 10 common soil contaminants. $1 \mu \mathrm{l}$ of diluted DNA templates from the above mentioned samples were amplified by using universal primers ITS1 and ITS4 for amplifying the entire ITS region by the reaction conditions as mentioned above. A second amplification with species specific primer set 
was conducted by using $1 \mu \mathrm{LNA}$ templates from the previous amplification. Only 15 cycles were run with denaturation at $94^{\circ} \mathrm{C}$ for $30 \mathrm{sec}$ and an annealing temperature of $56^{\circ} \mathrm{C}$ for $45 \mathrm{sec}$ to increase specificity. Negative controls were included in all the tests.

PCR products were separated by gel electrophoresis on $1.3 \%$ agarose in TAE buffer and visualized by UV fluorescence.

\section{RESULTS AND DISCUSSION:}

Identification of pathogen: The identification of $C$. quinqueseptatum was done by the key described by Crous and Wingfield (1994). The microscopic characters of conidiophores on carnation leaf agar were as follows.

Macroconidiophore: Stipe septate, hyaline, terminating in a clavate vesicle, (3-)5(-6) $\mu \mathrm{m}$ diam.; stipes (150-)275(-380) $\mu \mathrm{m}$ long. Conidiophores branches: primary branches non-setate or rarely 1septate, $\quad(20-) 28(-55) \times(3-) 5(-6) \quad \mu \mathrm{m}$; secondary branches non septate, (15-)17(-20)x(3-)4(-5) $\mu \mathrm{m}$; tertiary branches (and other branches up to six), non septate, (12-)15(-19)x(3-)4(5-) $\quad \mu \mathrm{m}$. Phialides cylindrical to allantoids or slightly doliform, hyaline,

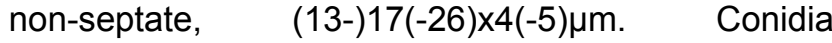
cylindrical, hyaline, (1-)5(6-)-septate, round at both ends, (61-)84(-101)x(5-)6(-7) $\mu \mathrm{m}$.

Microconidiophore: Stipe septate, hyaline, terminating in a clavate to sphaeropedunculate vesicle when present. Conidiophores branches:

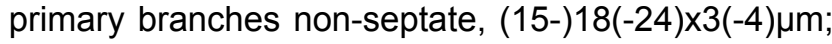
secondary branches non-septate, (8-)12(-18)x(2-)3(4) $\mu \mathrm{m}$. phialides arise singly from the ends of branches, or are arranged in groups of 2-4, cylindrical

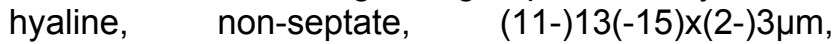
collarettes absent. Conidia cylindrical, hyaline, 1-

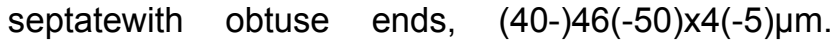
Sequences from the ITS1 and ITS2 along with $5.8 \mathrm{~s}$ rDNA gene of our 26 isolates of $C$. quinqueseptatum were BLAST searched from $\mathrm{NCBI}$ data base confirming their taxonomic identity.

Sequence analysis: A DNA fragment of approximately 492 bp from ITS region was amplified from 26 C. quinqueseptatum isolates using the universal primers ITS1/ITS4 and were sequenced. After alignment some intraspecific variability was found in the ITS sequences within our collections of C. quinqueseptatum. Based on multiple sequence alignment which included 26 isolates of $C$. quinqueseptatum of our collection, published sequences of C. quinqueseptatum (AF232868, AF232869, AF232870) and sequences of other species of Cylindrocladium available in GenBank, candidate primers were chosen from the regions of the greatest sequence dissimilarity among species. Several regions of marked sequence dissimilarity exist among the different species, a result that was not unexpected since the species were all members of different taxonomic groups. Of three $C$. quinqueseptatum primers initially tested, one set of primer which provided the most consistent and specific DNA amplification following optimization of the deoxynucleoside triphosphate concentration and other variables was chosen for further validation. The primer pair selected for specific amplification of $C$. quinqueseotatum was ITSFCQ-1f (5'ATCTCTTGGTTCTGGCATGC3') and ITSFCQ-1r (5'GAGACTCCAGAGCGAGGTGT3'). The specificity of the selected primer set is illustrated in fig-2 a \& b. Amplification by universal primer ITS1/ITS4 was observed in the DNA samples from all the fungal species. Amplification results of common Eucalyptus pathogens are shown in fig 1 . We amplified DNA product obtained with ITS1/ITS4 from 26 isolates of C. quinqueseptatum and other common Eucalyptus pathogens viz., C. scoparium, Botrytis cinerea, Cryptosporiopsis eucalypti, Alternaria alternata, Phaeophleospora sp and Pestalotiopsis sp and ten common soil fungi mentioned earlier with ITSFCQ $1 \mathrm{f}$ and ITSFCQ 1r. None of the isolates yielded PCR product other than $C$. quiqueseptatum isolates.

Primers ITSFCQ-1f and ITSFCQ-1r were tested for their ability to amplify DNA from $C$. quinqueseptatum cultures as well as from diseased Eucalyptus tissues and soil samples. Amplification of $245 \mathrm{bp}$ was obtained with the species specific primer from DNA templates extracted from infected leaf and twig samples from nurseries and plantations, leaves collected after six days of artificial inoculation of seedlings and from the soil samples. No amplification was found in healthy leaves and twigs samples and also from artificially inoculated leaf samples collected from seedlings less than six days after inoculation. DNA template from diseased tissues and soil samples from Eucalyptus nurseries and plantations showed positive results for PCR assay. Typical leaf blight disease symptoms appeared after 9 days of inoculation, however, the disease was detected by species specific primer only after 6 days of inoculation. All the diseased tissue samples, soil samples and samples collected after 12 days of inoculation were subjected to isolation of the 
pathogen. C. quinqueseptatum was isolated from all these samples confirming its presence.

Presently, detection of Cylindrocladium leaf and seedling blight solely depends on visual observations including microscopic examination of the samples and pathogen cultures, requiring an experienced fungal taxonomist and is a time taking process. Often the conidia formation requires specific medium for sporulation. Until the pathogen sporulates on plant tissues or in the culture, it is not possible to identify it. We have developed a PCR assay based on sequence analysis of internal transcribed spacer region of rDNA from $C$. quinqueseptatum which enable us to detect the pathogen within 9 to 10 hours which is not possible with the classical pathological methods.

The work presented here illustrates the potential for detecting the pathogen directly from infected seedlings with a minimum manipulation. This approach is particularly well suited to soil organisms that are difficult to identify or isolate because of the presence of other aggressive species. We have compared several extraction protocols and found that the one used here was the most reliable.

Amplification of species specific PCR products directly from DNA extracts from the diseased leaves and twigs without a first round of fungus specific amplification was not very consistent, probably because of the variability in the ratio of target DNA to non target DNA.

In contrast to this the nested PCR approach yielded highly consistent and reproducible results. The first amplification with fungus specific primers preferentially increased the population of fungal ITS molecules, thereby increasing the ratio of fungal by host ITS molecules. Competition between the two PCR products was apparently reduced during the second round of amplification since large numbers of ITS molecules served as a template to the species specific primers.

Detection with PCR assay was concordant with results from the isolation procedure. All seedlings infected by $C$. quinqueseptatum tested positive with PCR assay. In addition this fungus was detected by PCR in soil samples collected from different nurseries.

Specific primer set designed to identify $C$. quinqueseptatum was unable to amplify the template
DNA from other common Eucalyptus pathogens viz, Cryptosporiopsis eucalypti, Phaeophleospora sp, Alternaria sp, Botrytis cinerea, Pestalotiopsis sp and Cylindrocladium scoparium and 10 common contaminates viz. Aspergillus niger, $A$. flavus, Trichoderma harzianum, $T$. viride, $T$. koningii, $T$. virens, Fusarium sp, Phomopsis sp, Penicililum sp. And Cladosporium sp and DNA templates of other fungi obtained from NTCC viz., Fusarium solani, Colletotrichum gloeosporioides, Pycnoporus sanguineus, Trametes versicolor and Ganoderma lucidum. This shows the species specificity of the designed primer and thus, could be directly used for plant and soil samples obtained from the field. BLAST search results reveals that all the Cylindrocladium isolates collected from North India belong to only one species i.e. C. quinquiseptatum. However, from South India around 10 species of Cylindrocladium are reported. Absence of other species in North India may be mainly on account of the differences in climatic conditions and partially due to the physical distance between the two parts of the country.

CONCLUSION:

With the increased threat posed by this pathogen in nurseries of North India, the PCR assay we described provides a noble tool to detect $C$. quinqueseptatum in Eucalyptus planting stocks with greater sensitivity than was previously possible by traditional methods and hence to reduce the potential for transmission of the pathogen to new areas through planting material. The detection of $C$. quinqueseptatum by PCR assay method before the appearance of visible symptoms indicates that the assay may prove useful in determining the level of latent infection in symptomless planting materials. Hamelin et al., (1996) designed species specific primers for Cylindrocladium floridanum and Cylindrocarpon destructans using ITS region of rDNA. Similarly Henricot and Culham (2002) observed that the changes in the ITS sequences in all the isolates of $C$. buxicola in his study were consistent and can be used as one of the criteria to differentiate new species. The $C$. quinquesepttaum specific primer will be useful in selecting pathogen free nursery sites, analyzing potting mixture soils, disease forecasting, monitoring disease movement across different regions and detecting perpetual disease inoculum source such as diseased Eucalyptus trees adjoining nurseries apart from authentic identification of this pathogen and designing protection strategies. 
Agric. Biol. J. N. Am., 2010, 1(6): 1253-1259

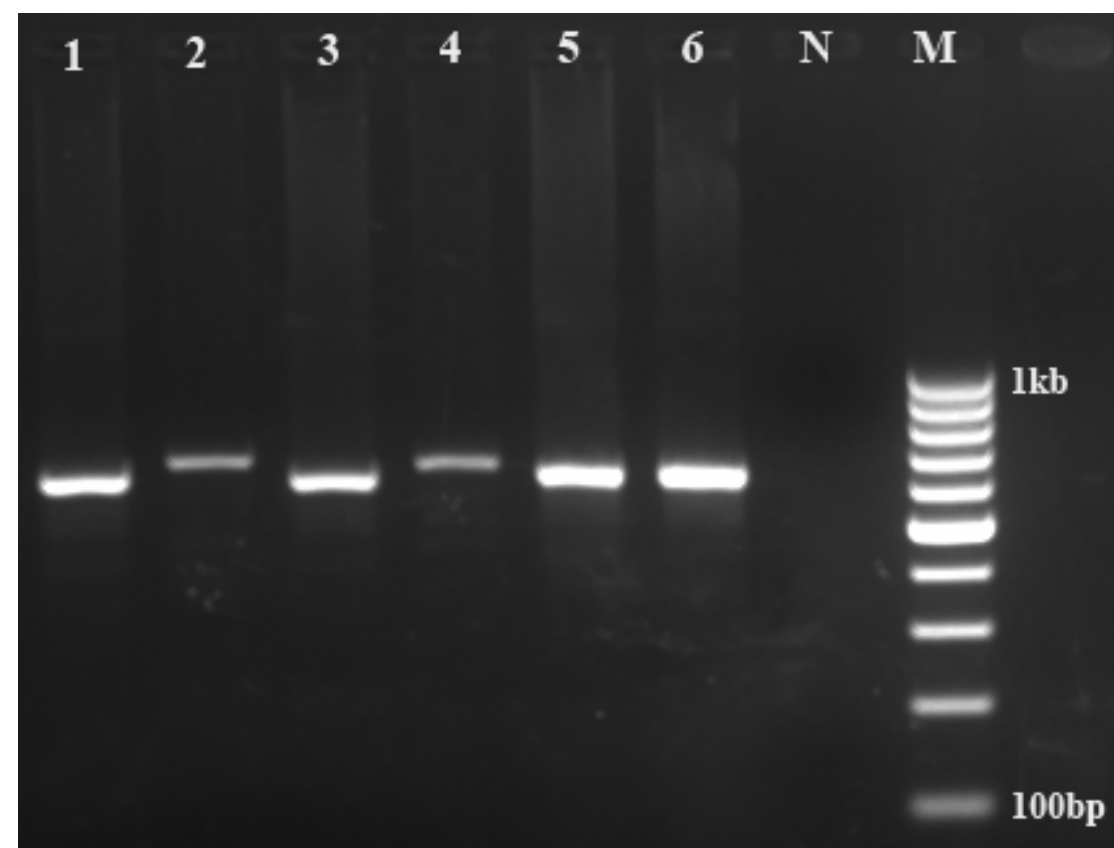

Fig1: Amplification of ITS regions of six common Eucalyptus pathogens by universal primers ITS1 and ITS4. Lane 1 Cryptosporiopsis eucalypti, Lane 2 Botrytis cinerea, Lane 3 Phaeophleospora sp, Lane 4 Pestalotiopsis sp Lane 5 Alternaria sp, and Lane 6 Cylindrocladium scoparium and negative control in Lane 7.

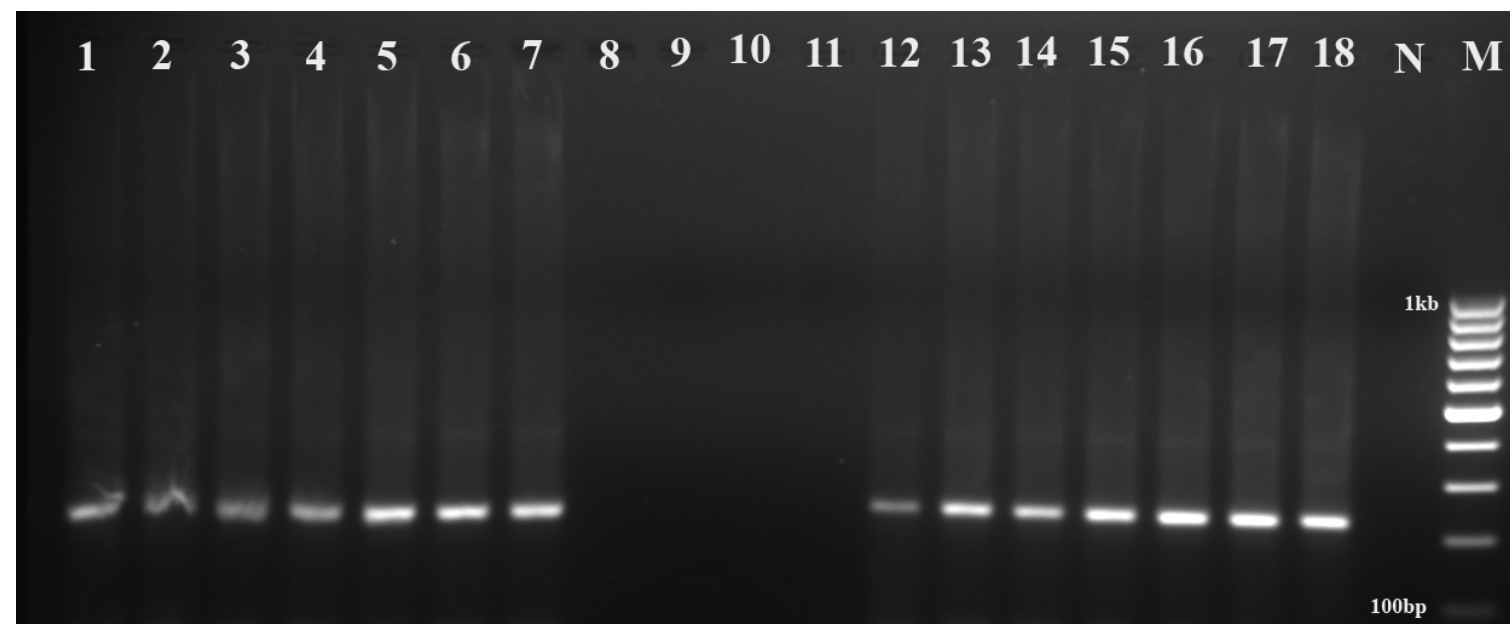

Fig2(a): Amplification of ITS region by specific primer set designed for Cylindrocladium quinqueseptatum. Lane 1 and 2 represents the amplification of DNA isolated from post inoculation pre symptomatic seedlings, lane 3 to 7 show amplification from diseased tissue samples, lane 8 and 9 from healthy leaves, lane 10 and 11 from uncontaminated nursery soil samples, lane 13 to 18 from $C$. quinqueseptaum cultures of different isolates. 
Agric. Biol. J. N. Am., 2010, 1(6): 1253-1259

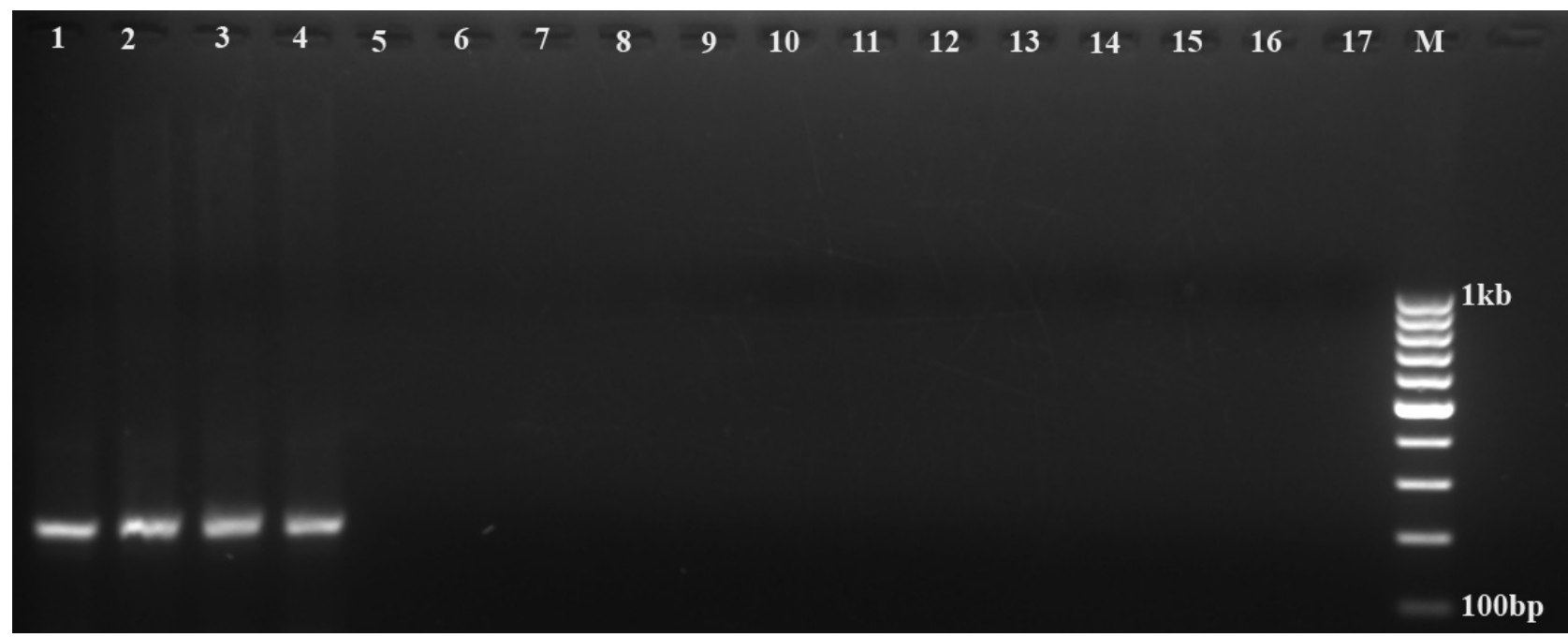

Fig2(b): Amplification of ITS region by specific primer set designed for Cylindrocladium quinqueseptatum. Lane 1 to 4 show the amplification of DNA isolated from the sick nursery soil samples, lane 5 to 16 show no amplification in DNA samples of two isolates each of six common Eucalyptus pathogens.

\section{REFERENCES}

Camele, I., Altieri, L., Vitale, A and Polizzi, G (2009). Development of PCR primers for detection of Cylindrocladium pauciramosum. Journal of Plant Pathology. 91:225-230

Chen, W (1992). Restriction fragment length polymorphism in enzymatically amplified ribosomal DNAs of the three heterothallic Pythium species. Phytopathology. $82: 1467-1472$

Grades, M and Bruns, T.D (1993). ITS primers with enhanced specificity for basidiomycetes-application to the identification of mycorrhizae and rusts. Mol. Ecol. 2:113-118

Hadidi, A., Levy, L and Podleckis, E.V (1995). Polymerase chain reaction technology in plant pathology. In: Singh RP, and Singh US. (eds) Molecular methods in plant pathology. CRC Press, Inc., Boca Raton, Fla, pp167187

Hamelin, R.C., Berube, P., Gignac, M and Bourassa, M (1996). Identification of root rot fungi in nursery seedlings by nested multiplex PCR. Applied and Environmental Microbiology. 62:4026-4031

Henricot, B and Culham, A (2002). Cylindrocladium buxicola, a new species affecting Buxus spp., and its phylogenetic status. Mycologia. 94:980-997

Henson, J.M and French, R (1993). The polymerase chain reaction and plant disease diagnosis. Annu. Rev. Phytopathol. 31:81-109

Nazar, R.N., Schmidt, X.Hu.J., Culham, D and Robb, J (1991). Potential use of PCR amplified ribosomal intergenic sequences in the detection and differentiation of Verticillium wilt pathogens. Physiol. Mol. Plant Pathol. 39:1-11

O'Donnell, K (1992). Ribosomal DNA internal transcribed spacers are highly divergent in the phytopathogenic ascomycete Fusarium sambucinum (Gibberella pulicaris). Curr. Genet. 22:213-220

Saghai-Maroof, M. A., Soliman, K., Jorgensen, R. A and Allard, R. W (1984). Ribosomal DNA spacer length polymorphisms in barley: Mendelian inheritance, chromosomal location and population dynamics. Proceedings of National Academy of Sciences. 81:8014-8018

Sharma, J. K and Mohanan, C (1982). Cylindrocladium spp. associated with various diseases of Eucalyptus in Kerala. Eur. J. For. Path. 20:15-23

Tooley, P.W., Bunyard, B.A., Carras, M.M and Hatziloukas (1997). Development of PCR primers from internal transcribed spacer region 2 for detection of Phytophora species infecting potatoes. Applied and Environmental Microbiology. 63:1467-1475

Vazquez-Marrufo, G., Vazquez-Garciduenas, MA. S., Gomez-Luna, B and Olalde-Portugal, V (2002). DNA isolation from forest soil suitable for PCR assay of fungal and plant rRNA genes. Plant. Mol. Biol. Rep. 20:379-390

Yao, C., Frederiksen, R.A and Magill, C (1992). Length heterogeneity in ITS2 and methylation status of CCGG and GCGC sites in the rRNA genes of the genus Peronosclerospora. Curr. Genet. 22:415-420

Zolan, M. E and Pukkila, P. J (1986). Inheritance of DNA methylation in Coprinus cinereus. Mol. Cell. Biol. 6:195-200. 